Fishing gear

\title{
APPLICATION OF HYDROA COUSTIC TECHNIQUES TO EXPLOITATION OF BIOLOGICAL RESOURCES OF THE SEA
}

\author{
ZASTOSOWANIE METOD HYDROAKUSTYCZNYCH \\ W EKSPLOATACJI BIOLOGICZNYCH ZASOBÓW MÓRZ
}

Department of Fishing Techniques, University of Agriculture, Szczecin, Poland

The paper discusses application of hydroacoustic methods in fishing techniques, with a particular reference to exploitation of biological resources of the sea.

Application of hydroacoustic methods in exploitation of living marine resources is considered with respect to the following areas:

- determination of marine environmental parameters,

- determination of the nature and behaviour of fish shoals and fish resource assessment,

- determination of fishing gear performance parameters and magnitude of catch,

- application of hydroacoustic techniques in ichthyology.

\section{INTRODUCTION}

The modern man looks towards the sea with keener and keener interest. The rational exploitation and management of the sea's living resources as one of major food supply is an important problem of today's world. The conviction that the seas and oceans ought to be known better and their resources exploited in a more rational manner is widespread. To what degree the living resources of the world's ocean can be used by the mankind depends 
to a certain extent on the technological potential and on international political and economic relations which affect the legal status of the sea as an area of human activity. Since the beginnings of his existence on this planet, the man has been increasing the extent of his exploitation of marine resources in close connection with his natural attraction to the sea. The fisheries provide a prime example of such a relationship.

To be highly effective, any fishery has to operate a gear appropriately adapted to both a fishing ground and peculiarities of life and behaviour of fish concentrations which are in constant motion and perpetually change. In practice, solving those problems stumbles on serious difficulties resulting both from the lack of full information on the environment and target species as well as from the fact that the gear's effects on organisms and disturbances it produces in the environment are beyond control.

Hydroacoustics and computerized integration systems are more and more frequently applied to obtain information on the environment, target species, and the fishing system. Fig. 1 shows diagrammatically how information for fisheries can be obtained using, i.a. hydroacoustic methods.

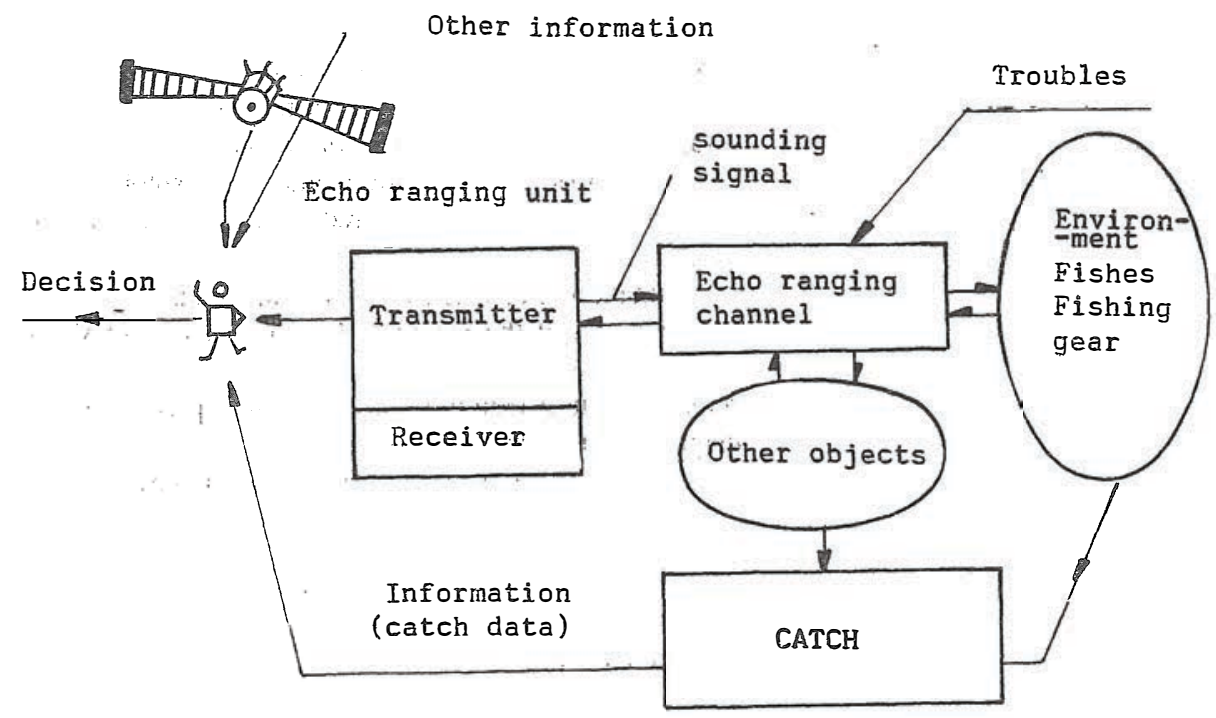

Fig. 1. Block diagram of information acquisition on fish by means of hydrelocation system and control hauls 


\section{HYDROACOUSTIC METHODS FOR COLLECTING INFORMATION ON THE ENVIRONMENT, RESOURCES, AND THEIR BEHAVIOUR}

Hydroacoustics in exploitation of biological resources of the sea is used to:

- determine parameters of the aquatic environment,

- describe the nature and behaviour of fish concentrations and to assess their abundance,

- determine working parameters of the gear and magnitude of catch,

- collect ichthyological data.

It has been a tradition to separate theoretical and practical aspects of the fields listed above. Nowadays, however, a strong tendency to integrate both aspects is evident.

A significant progress has been made recently and one can expect that the progress will continue in the nearest future. The fisheries will more and more frequently use international information systems such as the Geographic Information System (GIS) and the Global Environmental Monitoring System (GEMS). The use of computers and integrated information systems allows to obtain, via the systems mentioned, updated environmental data, to store, process, analyze and present them in a concise way in tables, graphs, and maps (Fig. 2).

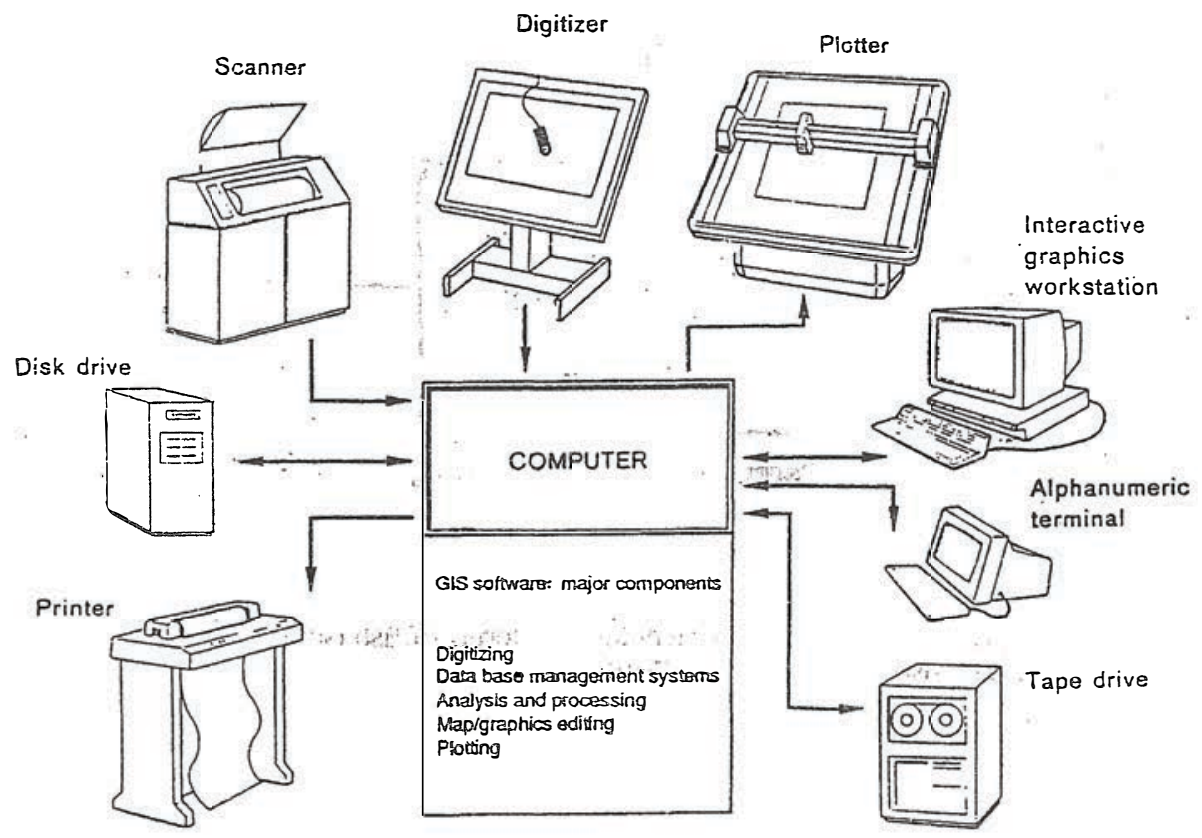

Fig. 2. GIS main hardware and software components (Garcia and Kapetsky, 1991) 
GIS has been increasingly commonly used to produce geographic inventories of resources, including those of aquatic environments, and to answer questions as to "where", "what", and "how much". With respect to aquatic environments, GIS makes it possible to integrate information on resources and habitat obtained from different sources, e.g. hydroacoustic data (including remotely controlled mobile surveys), catch data, and data re-sulting from the use of satellites.

The present development $\bullet$ marine acoustic fjsheries, encompassing, i.a. theory of acoustics, electronics, oceanography, hydrology, biology, physiology and behaviour of organisms, and biostatistics involves integrations of studies and technical solutions. Both the research and the market need integrated systems able to supply information on environmental parameters, zooplankton, distribution and abundance of fish, and their behaviour. That means that an echo sounder is but one of the sensors used in the information gathering system and process; it is no more an autonomous piece of equipment, but works as one of the sensors in monitoring the marine environment (Fig. 3).

\section{SYSTEM}

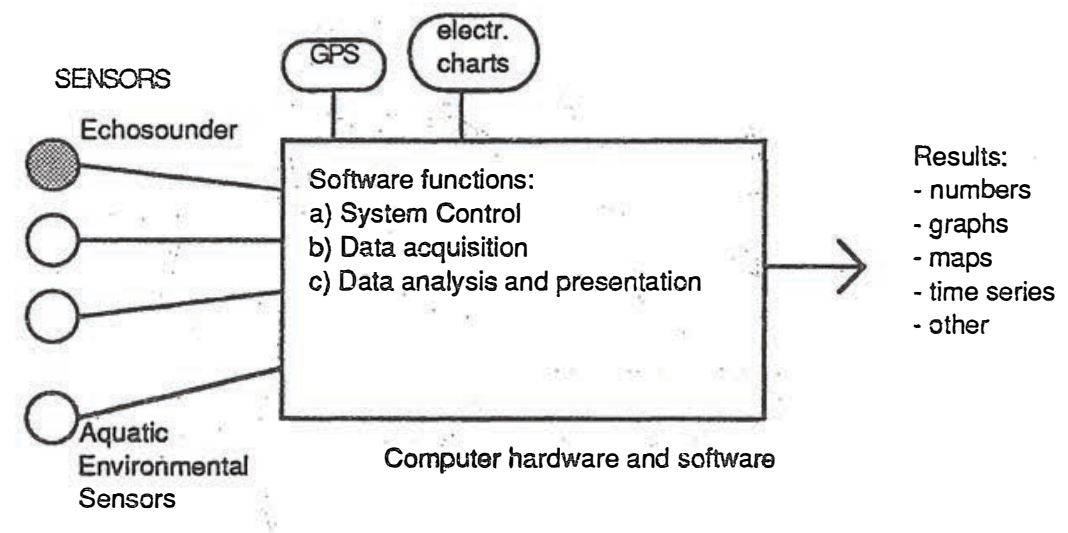

Fig. 3. Block diagram of hydroacoustic system for monitoring of fish rsources by aquatic environmental sensors (Johnson and Griffiths, 1990) 
The user today, whether a scientist or a manager, demands up-to-date direct infmation on the environment and organisms localized in time and space, so that the information - without any lengthy analysis - could serve as a basis for a fast decision making process and prompt action. To this end, the necessary information is provided in the form of, i.a., maps (Bioacustic Mapping System) presenting environmental parameters and resource allocation in terms of depth, density, and temporal distribution. The Bioacoustic Sensor Subsystem (Fig. 4) is one of the elements of the Bioacoustic Mapping System.

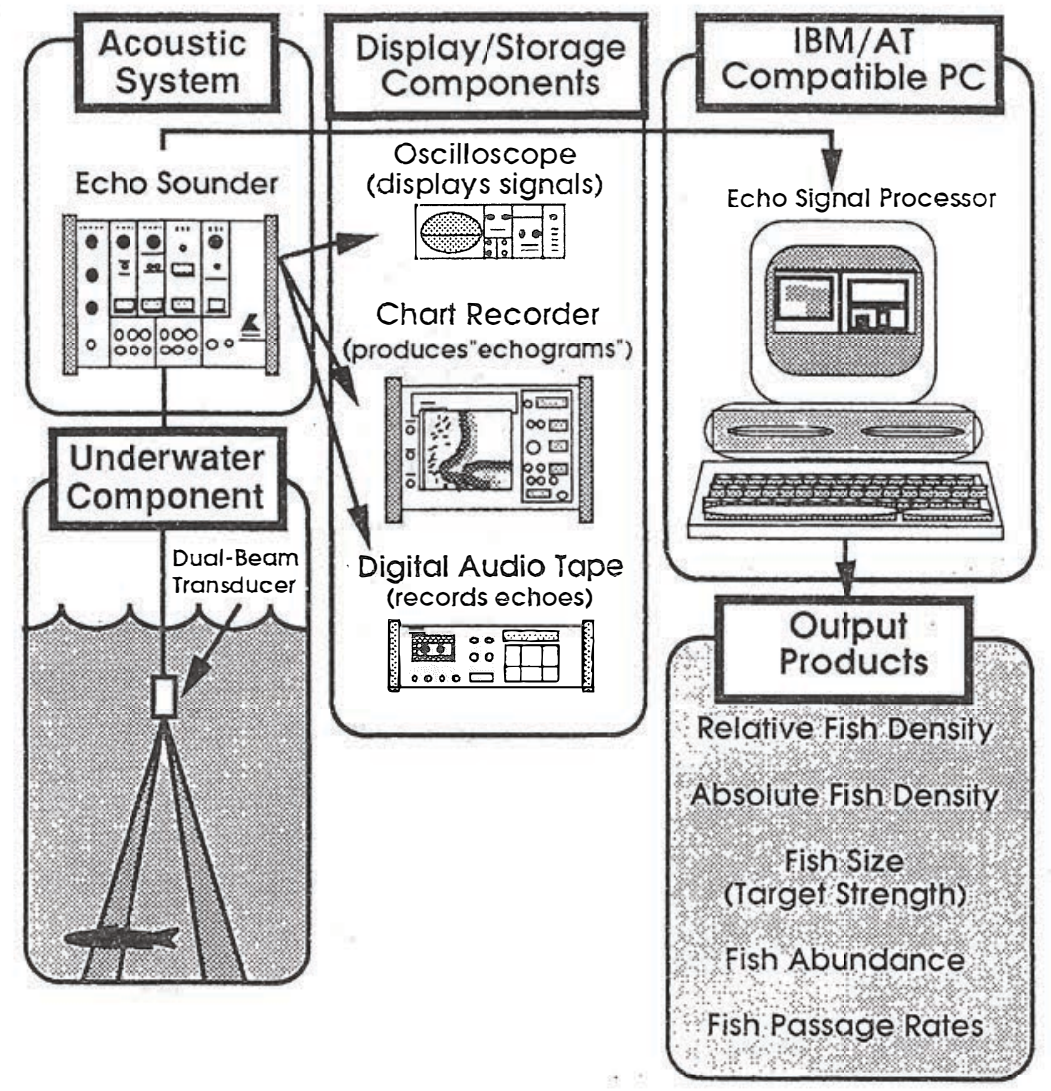

Fig. 4. Components of a fisheries acoustic system and examples of results 


\section{APPLICATION OF HYDROACOUSTICS TO DETERMINATION OF MARINE ENVIRONMENTAL PARAMETERS}

Fish resources and characteristics of fish concentrations depend on numerous biotic and abiotic factors of the marine environment. At present, an ecologically optimal exploitation of biological resources at the sustained yield level is preferred and related to maintaining the marine ecosystem in equilibrium: with respect to both is biotic and abiotic components. The ecologically sound exploitation has to result from knowledge on the basic environmental parameters, their interactions, and effects on the resources as well as on the formation and behaviour of fish concentrations. Particularly important from the fisheries standpoint are data on a fishing ground depth, bottom characteristics, temperature, salinity, currents, zooplankton, and pollution.

The modern technology provides ways to make observations and accrete information on the status of biological resources in relation to their environment. Hydroacoustic methods allow to develop and apply synthetic mathematical models on the ecosystem the fish are part of. Similarly to the need of monitoring the state of air, soil and inland water bodies, a rational exploitation of biological resources of the sea calls for collecting up-to date information on the environment. Similarly to the task of measuring various environmental parameters in cities and other inland areas, there is a need to monitor such parameters in marine areas; there, however, additional information on the magnitude and behaviour of biological resources has to be collected as well.

GIS is being utilized in numerous FAO projects involving fisheries development and management. An example is provided by application of GIS to develop aquaculture in the Nicoya Bay (Costa Rica). The environmental data (temperature, salinity, oxygen content, currents, depth, chlorophyll content) collected by the Bioacoustic Mapping System have made it possible to delineate preferred culture sites for various species (Garcia and Kapetsky, 1991; BioSonics, 1991). GIS is also used in similar FAO programs in Asia, Latin America, and Africa. The system has been most widely and successfully used in the USA, Canada, Great Britain, and France (European Marine Digital ATLAS).

Species composition of the plankton is a very important indicator of the state of aquatic environment. The small size of zooplankters call for acoustic equipment adjusted to the target strength; primarily, a higher frequency and narrower beam width are necessary. At present, apparatus utilizing $420 \mathrm{kHz}$ or $1 \mathrm{MHz}$ frequencies, 3-10 beam width and $0.3 \mathrm{~ms}$ is used. A novelty and, at the same time, a characteristic feature of hydroacoustic systems to monitor the zooplankton is the fact that they are composed of two elements, one operating on the surface and another working under water (Fig. 5). 


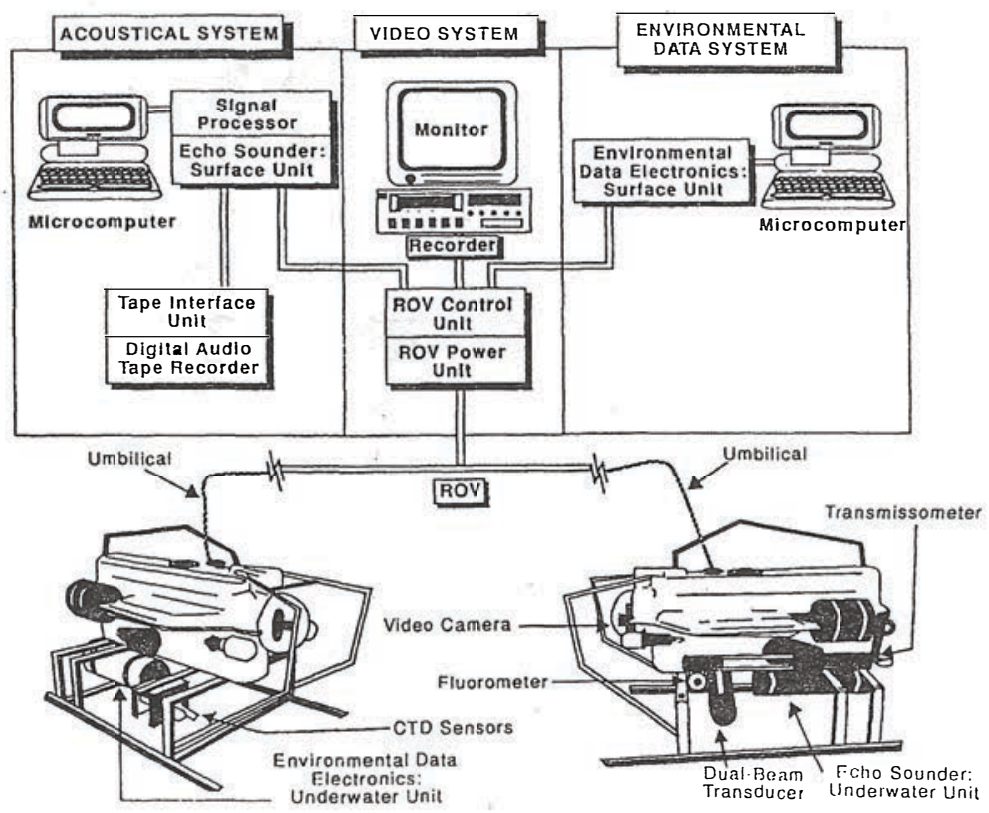

Fig. 5. Modified Benthos SeaRover ROV with remote SONAR system and other environmental sensors deployed (Johnson and Griffiths, 1990)

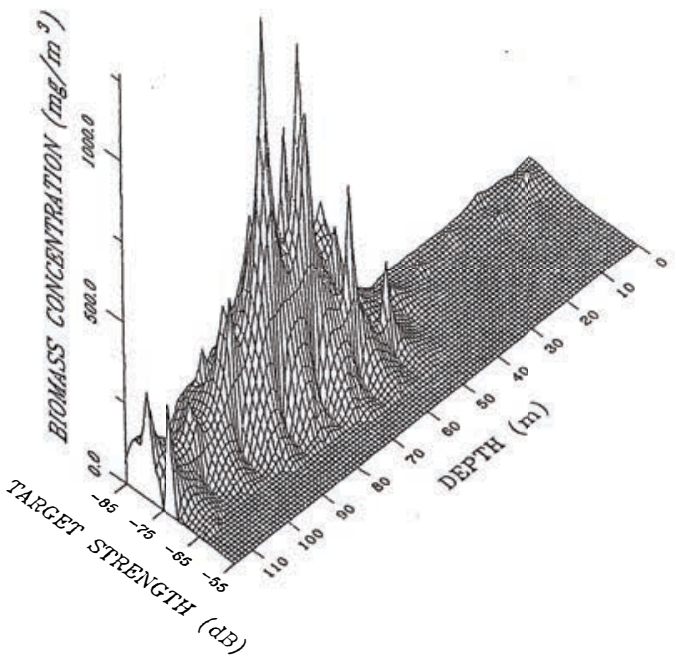

Fig. 6. Vertical profiles of numerical density and biomass concentration apportioned to acoustical target strength classes (Johnson and Griffiths, 1990)
The transects are surveyed with a vertical transducer (a classic application) and also with a horizontal transducer mounted on a Remotely Operated Vehicle (ROV), a research submarine or on a special buoy. The results are displayed as three-dimensional graphs (Fig. 6) (Johnson and Griffiths, 1990). Fig, 7 and 8 show echograms of krill (Euphausia superba Dana) swarms on the South Georgia fishing grounds, obtained with traditional echo sounding. 


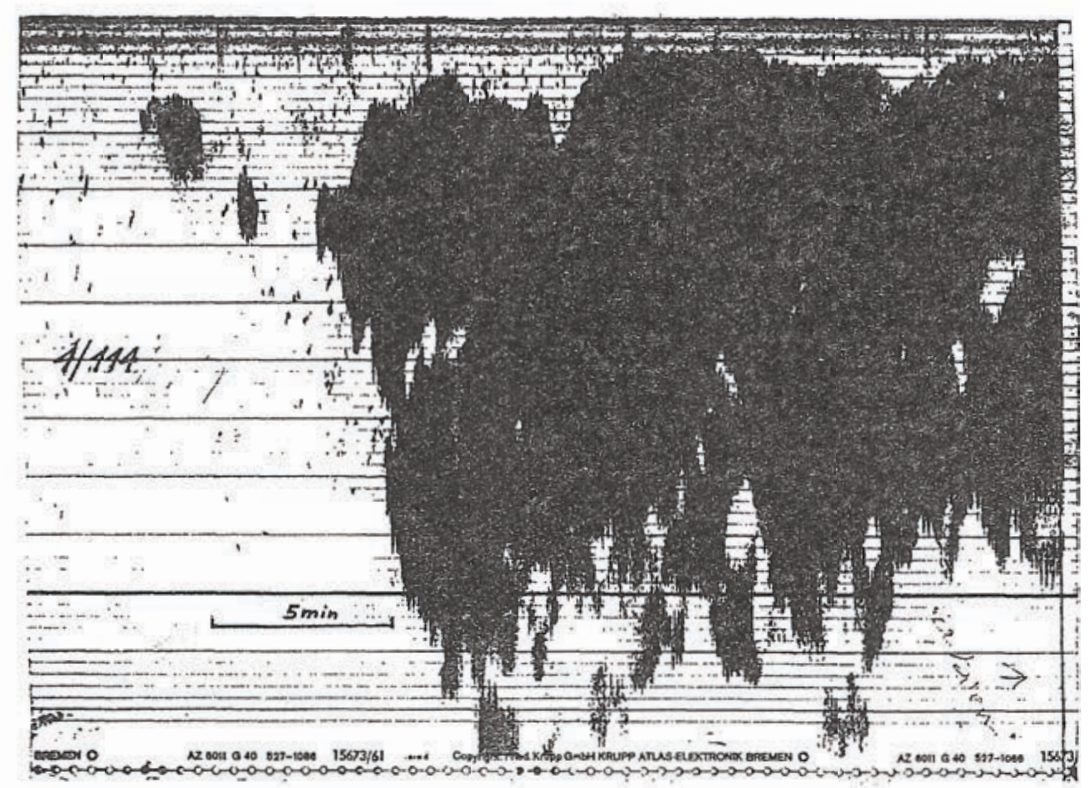

Fig. 7. Echographs of krill schoal euphasia superba Dana, South Georgia, $10^{10}-10^{50}$, 15 ton, m/t "Gemini" 1977, Fischfinder 790 DS, Krupp ATLAS Elektrønik

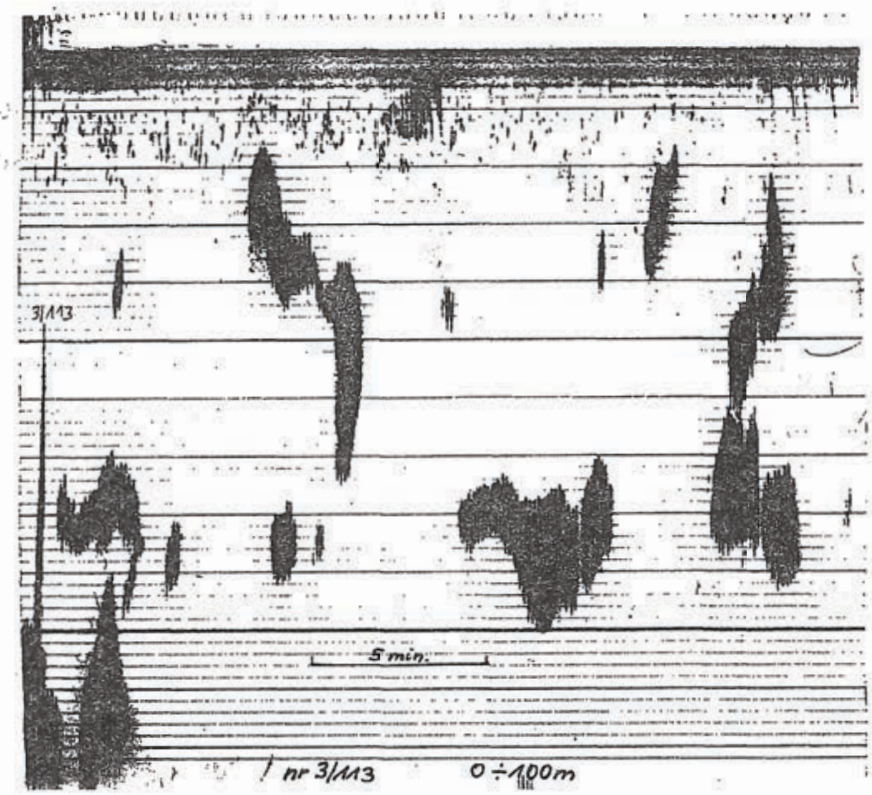

Fig. 8. Echographs of krill schoal Euphasia superba Dana, South Georgia, $6^{00}-8^{25}$, 6 ton, m/t "Gemini" 1977, Fischfinder 790 DS, Krupp ATLAS Elektronik 
Another BioSonics development is remote acoustic sampling and data transfer via telephone lines (Fig. 9). The echo sounder and a transducer are mounted permanently in an area, while the data are received via telephone lines and processed in Seattle, the echo sounder being remotely controlled by a computer (personal communication by J. Burczyński, BioSonics, Seattle, WA 98103, USA).

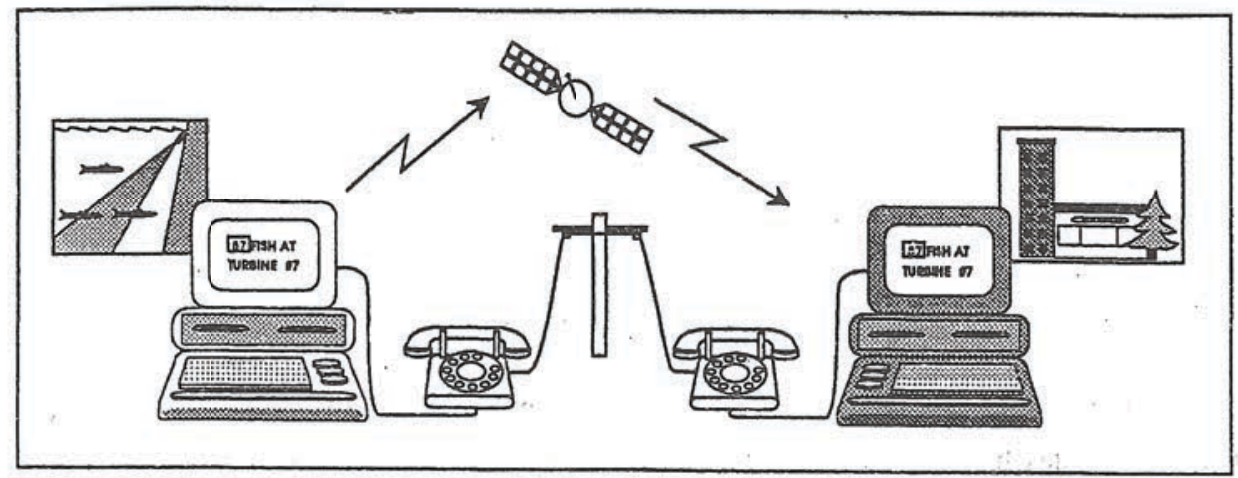

Fig. 9. Automatically transmitting environmental data from the study site to a cental location where it can be analyzed

Polish scientists can boast considerable achievements in the field (Burczyński et al., 1973; Stepnowski, 1991). Of a particular interest are studies and results of A. Orłowski, presented in his dissertation "Application of acoustic methods to study distribution of fish and scattering layers in relation to the marine environment" (Orłowski, 1989). Among other problems, the author deals with static and dynamic resource assessment and casts his discussion against the backdrop of the marine environment and the existing interactions. Oriowski presents a number of methods aimed at solving the problems outlined above and incorporating hydroacoustic techniques and applied to, i.a., the Baltic Sea. One of the results is an atlas of fish distribution in relation to the environment and the nature of the bottom.

\section{HYDROACOUSTIC METHODS USED IN DETERMINATION OF FISH CONCENTRATIONS AND RESOURCE ASSESSMENT}

To determine the nature of fish concentrations, direction of their movements, and their length distribution and species composition as well as to assess abundance of the resources, physical sampling and remote sampling are used. The sampling techniques are summarized in Table 1. 
Table 1

Sampling techniques used in determining fish concentrations

\begin{tabular}{|l|l|c|c|}
\hline Category & Technique & \multicolumn{2}{|c|}{ Sampling } \\
\cline { 2 - 4 } & & Fixed & Mobile \\
\hline Physical & Nets & $\mathrm{x}$ & $\mathrm{x}$ \\
& Traps & $\mathrm{x}$ & $\mathrm{x}$ \\
& Electroshocking & $\mathrm{x}$ & $\mathrm{x}$ \\
& Tag and Recapture & $\mathrm{x}$ & $\mathrm{x}$ \\
& Toxicants and Explosives & $\mathrm{x}$ & $\mathrm{x}$ \\
& Egg and Larvae Surveys & $\mathrm{x}$ & $\mathrm{x}$ \\
\hline Physical/Remote & Radio or Sonic Tagging & $\mathrm{x}$ & $\mathrm{x}$ \\
& Catch Statistics & - & - \\
\hline Remote & Visual Observation & $\mathrm{x}$ & $\mathrm{x}$ \\
& Underwater Video & $\mathrm{x}$ & $\mathrm{x}$ \\
& Fisheries Acoustics & & \\
\hline
\end{tabular}

Hydroacoustic techniques have been used in this regard for many years. Recently, those techniques have become more advantageous in resource assessment and fish concentration description than the conventional methods, particularly the biostatistical ones. As reported by Stepnowski et al., (1992), hydroacoustic methods in ichthyology and resource assessment are attractive because they provide on-line information on the magnitude and nature of fish concentrations over a relatively large area; the information is highly accurate and reliable, the data are fast collected and processed, and the techniques are highly automated. Thus the hydroacoustic techniques are nowadays treated as standards. Moreover, one should add that hydroacoustic methods can be used in resource assessment on fishing grounds temporarily closed for fishing operations, in situations when fishing efforts and catches are kept secret, or whenever there is a need for a fast assessment of schools over vast areas and/or spawning concentrations.

There is a vast array of echo sounders in use at present, their capabilities to display information being very diverse. Most modern echo sounders use a fishing colour scope. Moreover, the echo sounders contain minicomputer systems for information processing and integration. Those echo sounders provided with a fishing colour scope and operating within a video plotter system involving a TV monitor and video recording (most frequently these are the multi-function colour video sounders) record the target objects in size-dependent different colours; the same applies also to the echograms produced. An important development is a possibility to record, both on a colour echogram and on a fishing colour scope, the fish length distribution along the transect sounded (e.g. 1 nautical mile long) (Fig. 10). As seen from Fig. 10, bottom sediment layers are colour coded as well. Fish length distribution as revealed by trawl data and target strength measurements is shown in Fig. 11. 


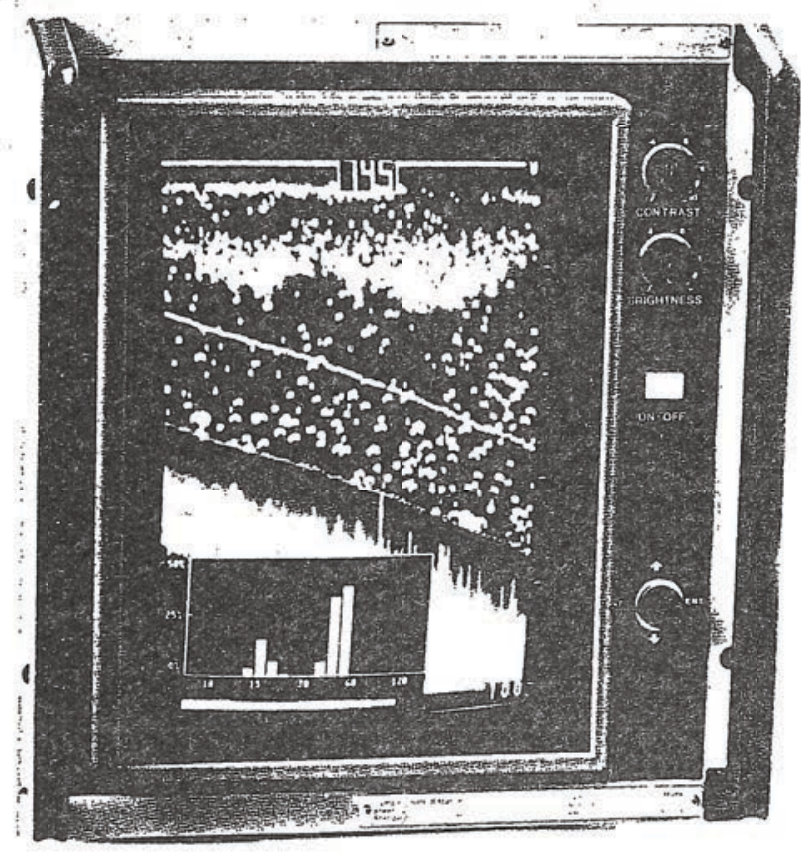

Fig. 10. Echogram of Simrad ES 380 colour sounder with size distribution diagram

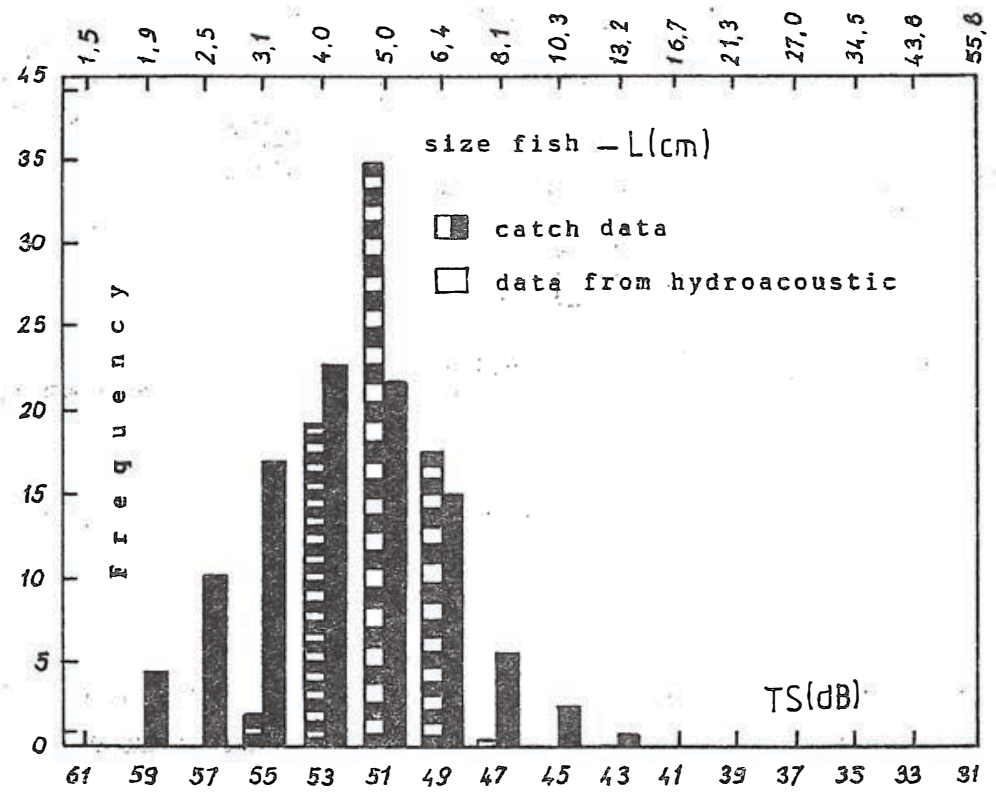

Fig. 11. Fish size distribution according to trawl catch and target strenght 
Vertical echo sounders provided with integrators are often used in studies of fish resources. The integrator integrates signals obtained by the echo sounder. By measuring (integrating) along standard distances ( 1 nautical mile) travelled by a ship, the number of fish can be determined when the sounding impulse frequency to vessel speed ratio is held constant.

Polish hydroacoustics engineers have contributed significantly to studies on hydroacoustic assessment of fish resources. Theoretical developments, constructions, and resource assessments worked out on board RV "Profesor Siedlecki" ((Burczyński et al., 1973) deserve a special mention as do recent studies of Stepnowski (Stepnowski, 1991; Stepnowski et al., 1992) on dual-beam method of target strength estimation to determine fish size and resources abundance. The Black Sea resources assessment system used by Stepnowski et al. (1992) is based on a principle illustrated in Fig. 12.

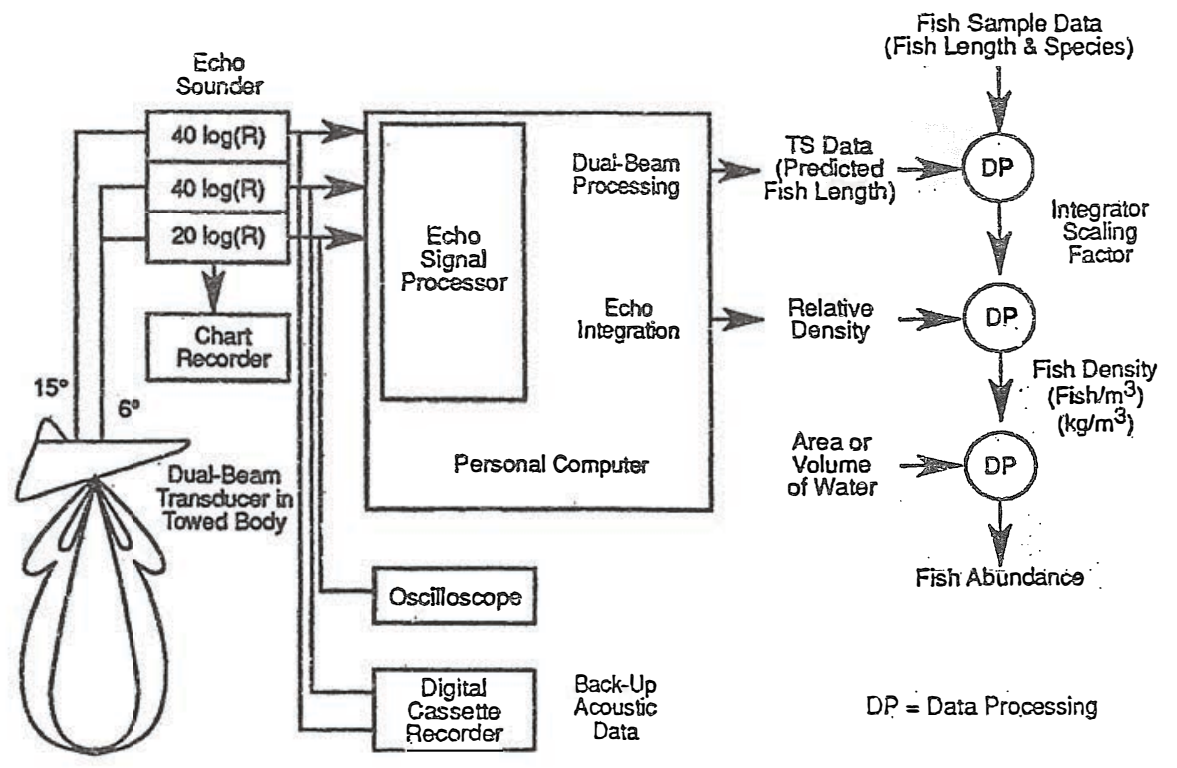

Fig. 12. The echo-integration (dual-beam processing system block diagram)

(Stepnowski et al., 1992)

At present, knowledge on diel cycles of different fish groups and on interactions between characteristics of living resources and abiotic parameters of the ecosystem is of a particular importance both in research and in a rational resource exploitation. For this reason, hydroacoustic methods are more and more commonly used to study diurnal and/or seasonal behaviours of different fish species. 


\section{APPLICATION OF HYDROACOUSTIC TECHNIQUES TO CONTROL OPERATION OF FISHING GEAR AND MAGNITUDE OF CATCH}

The problem is particularly important in trawl fisheries. The basic characteristics of the trawl is its mouth geometry and location relative to the water surface and the bottom. Net echo sounders are widely used to control location of the trawl in the water column. Moreover, net echo sounders make it possible to determine trawl's vertical opening and distribution of the fish relative to the trawl mouth and to conclude on the amount of fish in the codend. However, information on mouth geometry and on the amount of fish, obtained in this way, is not very accurate.

The idea to apply hydroacoustics in order to solve the problem was put forth in the '70s as the so-called integrated fishing system. Briefly, the system involves automation of the fishing process and integration of its different functions. The system involves, i.a., detection and identification of target organisms, monitoring their behaviour with relation to the vessel and gear, guiding the gear onto the target, control of gear performance, and control of the catch size.

A number of companies (Simrad, Scanmar, Atlas-Elektronik, Furuno) have been for several years developing systems and equipment which would provide information on environmental parameters, nature of fish concentrations, gear operation and catch size control. These efforts are devoted to constructing integrated and compatible systems which would allow detection and identification of fish concentrations, description of their behaviour as affected by disturbance from the vessel and gear, and control of the performance of the trawl (or other gear), including information on how big is the catch in the codend. An example is provided by the Scanmar Catch Control System. When applied to trawl fisheries, the system measures the following variables:

- horizontal distances between, e.g., doors, wing tips, or in the mouth,

- trawling depth, i.e. a distance between the foot rope and the bottom and between the head rope and the surface,

- trawl mouth gap,

- mouth shape,

- temperature at the fishing depth,

- trawl sinking and hoisting speed at vertical operations,

- amount of catch in the codend.

The results of measurements are displayed digitally and graphically on a colour monitor. Polish research centers (Gdańsk Technical University, Sea Fisheries Institute, University of Agriculture in Szczecin) have filed significant achievements in the field as well; the achievements include, i.a., designing and construction of electronic measurement 
system to study trawl models towed by a catamaran at the Academy of Agriculture's Model Research Station at Ińsko, the system being also adapted to work on board Baltic fishing boats (System TRAWL). The system consist of 4 measurement centers, 3 of them being placed underwater, directly on a model being tested (Fig. 13). The distances between measurement points are rather large, reaching in some cases several hundred meters. The response system is expected to measure: the trawl (model) - vessel (catamaran) distance, the centre A - centre B distance, and the distance between the doors. The foot rope - bottom distance will be measured with the aid of a echo sounder, while the remaining distancess will be measured by the so-called communication system (Świniarski et al., 1987).

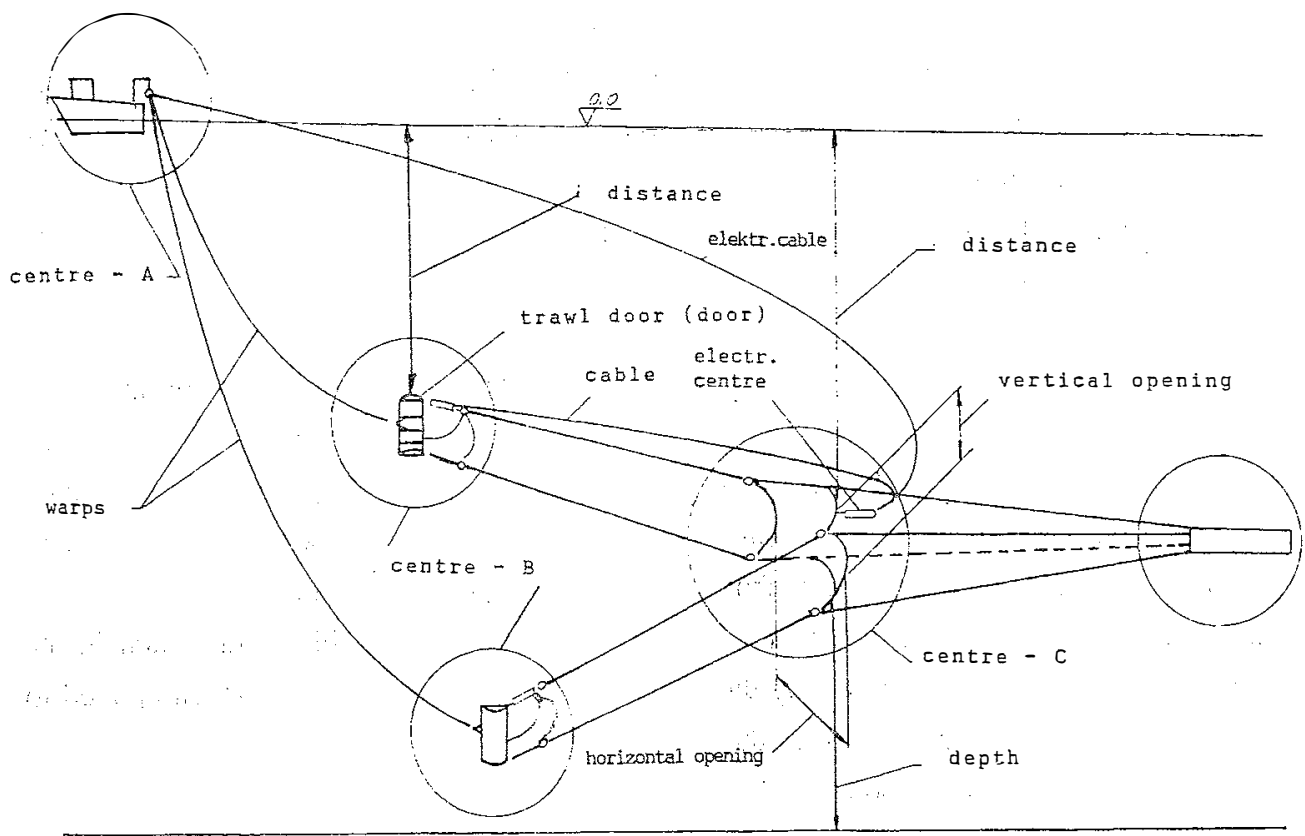

Fig. 13. Model trawl fishing system with measuring points

Information on the amount of fish in the codend during a fishing operation, based on the behaviour of individual trawl system elements, is of limited applicability, while information provided by ichthyolocation equipment is of limited accuracy. F $\bullet$ this reason, some companies (Simrad, Atlas-Elektronik, Furuno, Scanmar) have been developing systems and equipment providing information on the catch size in the codend during a fishing operation (trawl catch indicators). Equipment manufactured by Scanmar is at present most advanced and specialized. 
In Poland, due to a common use of cable net echo sounders on board Polish fishing vessels, it has been decided to construct a controller coupled with the sounders. Once the codend is filled with fish, the emitter mounted on the codend sends an acoustic signal to the net echo sounder float mounted on the head rope. The receiver in the float intercepts the signal, decodes it, and transmits, via the echo sounder cable, to the ship's bridge. The message that the codend is full is displayed on the echo sounder graphic recorded. The controller has been manufactured by the "Robot" company in cooperation with scientists from the Academy of Agriculture and Sea Fisheries Institute and has been tested, as a prototype, at sea.

\section{APPILICATION OF HYDROACOUSTIC TECHNIQUES IN ICHTHYOLOGY}

As shown by numerous studies, the fish do have hearing capabilities. Anatomically, the organ of hearing is particularly well developed in the Cypriniformes.

Generally, as shown by the research reported by Protasov (1965), the hearing organ spectral sensitivity range in those fish lacking the Weber apparatus and swim bladder is 10 - 10 to $210 \mathrm{~Hz}$, while the range in those provided with the Weber apparatus and swim bladder is much broader $(20-50$ to $510-610 \mathrm{~Hz})$. The lateral line organ can sense even lower values, its upper limit of detection being at $400-500 \mathrm{~Hz}$. The absolute fish hearing organ threshold is at 20-80 dB (Protasov, 1965). Regardless of being able to hear, the fish, crustaceans, and other aquatic organisms can themselves produce sounds (Mohr, 1965; Melnikov, 1973; Protasov, 1965).

Once the echo sounders were introduced to fisheries, a number of questions were raised, e.g. what effects the sounders might exert on aquatic organisms and whether the fish can be scared by the equipment of this type. Numerous studies in aquaria and in the sea failed to demonstrate a direct response of fish to the sound produced by the hydroacoustic apparatus used on research and fishing vessels (Mohr, 1965; Mohr, 1966).

Recently, studies employing direct observations from research submersibles and TV on fish reaction to gear and ultra sound equipment used on board vessels have become particularly important. Those studies failed, too, to demonstrate that fish responded to ultra sounds within the hydracoustic equipment waveband $(30-200 \mathrm{kHz}$ ) (Cetinic and Świniarski, 1985; Korotkov and Kuzmina, 1972).

Owing to the developments in electronics and microprocessing techniques, marine bioacoustics have been more and more commonly employed in ichthyological research during the present decade. Acoustic telemetry (biotelemetry) has become a widely applied technique. Apart from a traditional use of hydroacoustic equipment to determine the nature 
of fish concentrations, to assess the resources, and to control the gear performance, acoustic is being used to follow, in real time:

- horizontal and vertical migrations and swimming speed of fish,

- distribution and magnitude of fish concentrations in lakes, rivers, lagoons, channels, and ponds,

- reactions of single fish and their concentrations to natural and artificial stimuli,

-- mechanisms of fish concentration formation,

- numbers of fish migrating through gates of hydrotechnical constructions and gate efficiency,

- fish reactions to fishing gear,

- distribution of plankton and nekton, their concentration and biomass, and in:

- monitoring the marine environment,

- studies on physiology of aquatic animals,

- measurements of size of fish and other organisms,

- following migrations of salmonids in rivers and to facilitate the release of dammed water, containing migrating juvenile salmonids, from lakes to the sea,

- studies on distribution and assessment of resources of fish and other organisms in ice-bound lakes and seas.

\section{REFERENCES}

Burczyński J., A. Stepnowski, R. Salamom, W. Martim, 1973: A fish stock abundance system based on thin layers" and its use in board of RV "Profesor Siedlecki". Proceedings of ICES/FAO. Symposium on Acoustic Methods in Fisheries Research, Bergen, 19-22 June 1973, Paper No 44.

Cetimic P., J. Świmiarski, 1985: Alati i tehnika rybolova. Logos, Split.

Garcia S.M., J.M. Kapetsky, 1991: "Geographic Information System" GIS Applications for Fisheries and Aquaculture in FAO. Paper presented at "Marine resources atlases - An update". London, 17-18 October 1991.

Jonson G.E., W.B. Griffiths, 1990: Hydroäcoustic surveys of zooplankton biomass and distribution in the Beaufort Sea in 1985 and 1986. Rapp. P.-v. Réun. Cons. int. Explor. Mer., 189: $345-352$.

Korotkov V.K., A.S. Kuzmima, 1972: Tral, povedenije obiekta lova i podvodnyje nabludenija za nimi. Piščevaja promyšl., Moskva. (In Russian).

Melnikov V.N. Moskva. (In Russian).

Mohr H., 1965: Zur Ermittlung des Hörbereichsbeim Kabeljau (Gadus callarias L.). Protokolle zur Fischereitechnik, Hamburg, 9, 43.

Mohr H., 1966: Über die reaktion von Fischen auf Lotschall. Informationen fuit die Fischwirtschaft, No 4. 
Orlowski A., 1989: Zastosowanie akustycznych metod do badań rozmieszczenia ryb i warstw rozpraszających na tle środowiska morskiego. [Application of acoustic techniques to study distribution of fish and scattering layers in relation to the marine environment]. Studia i Materiały MIR Gdynia, ser. B, No 57. (In Polish).

Protasov V.R., 1965: Bioakustika ryb. Nauka, Moskva. (In Russian).

Stepnowski A., 1991: Zarys teorii i technika hydroakustycznych metod oceny siły celu i populacji ryb. [An outline of theory and techniques for hydroacoustic methods to assess target strength and fish populations]. Zesz. Nauk. Akademii Marynarki Wojennej w Gdyni, No. 111 C. (in Polish).

Stepnowski A., A.C. Gucu, F. Bingel, 1992: Assessment of the pelagic fish resources in the Southern Black Sea using echo integration and dual-beam processing. Arch. of Acoustics, Warszawa. (In press).

Świniarski J., P. Nowakowski, A. Emilianowicz, 1987: Zastosowanie systemów hydroakustycznych do pomiaru geometrii układu połowowego statck-włok. [Application of hydroacoustic systems to measure geometry of vessel-wawl fishing system]. 5th Symposium Hydroacoustics, Gdańsk-Gdynia. (In Polish).

The BioSonics Bioacoustic Mapping System. BioSonics, June, 1991.

Translated by: Dr T. Radziejewska

Józef ŚWINIARSKI

\section{ZASTOSOWANIE METOD HYDROAKUSTYCZNYCH W EKSPLOATACJI BIOLOGICZNYCH ZASOBÓW MÓRZ}

\section{STRESZCZENIE}

W pracy przedstawiono zastosowanie metod hydroakustycznych $\mathrm{w}$ technice rybackiej, ze szczególnym uwzglednieniem eksploatacji biologicznych zasobów mórz.

Stosowanie metod hydroakustycznych w eksploatacji biologicznych zasobów mórz rozpatrywane jest w następujących kierunkach:

- określanie parametrów środowiska morskiego,

- określanie charakteru i sposobu zachowania koncentracji rybnych oraz szacowanie ich zasobów,

- określanie parametrów pracy narzędzi połowu i ilości złowionych przez nie ryb,

- wykorzystanie technik hydroakustycznych w ichtiologii.

Received: 1992.07 .23

Author's address:

Prof. tit. D.Sc. Józef Świniarski

Department of Fishing Techniques

University of Agriculture in Szczecin

Kazimierza Królewicza 4

71-550 Szczecin

Polska (Poland) 